\title{
Nordslesvig i 1894, 95 og 96.
}

Af Gustav Juhannsen.

Efterat den nordslesvigske Befolkning i 1893 ved Rigsdagsvalget den 15. Juni og Landdagsvalget den 7. November havde konstateret baale Fremgang i Stemmetal og urokkelig Fastholden ved det gamle Løsen:

"Vi ere Danske, vi ville forblive Danske, og vi ville behandles som Danske efter Folkerettens Love!" optoges dens Interesse i 1894 særlig af den Virksomhed, de folkevalgte kirkelige Repræsentanter $0 g$ de af disse fremgaaede Provsti- og Falles-Synode-Medlemmer udfoldede i Sprogsagen. Men samtidig fulgtes ogsaa med sprendt Opmærksomhed Statskirkepræsternes Stillingtagen i denne, den danske Befolknings Hjertesag.

laa Provstisynoderne i Nordslesvig bragte Menighedernes valgte Repræsentanter Sprogsagen frem, og i mangt og meget af det, disse Lægmænd forte frem imod Sprogordningen af 18. December 1888, fanclt de Stsitte hos Statskirkepræsternes langt overvejende Flertal.

Syvtisyv nordslesvigske Praster havde i en Petition henvendt sig til den preussiske Kultusminister og bedt om, at der matte blive indført ugentlig 2 Timers Undorvisning i det danske Sprog i de nordslesvigske Folkeskoler. Men 
selv dette ylerst beskedne Ønske fandt ikke Naade hos alen strænge $\mathrm{Hr}$. Kultusminister.

Reyeringen i Slesvig og særlig dens daværende Overhoved, Overpræsident $v$. Steinmann, har aldrig vist Forstaaelse ligeoverfor den danske Befolknings Ønsker i Sprngsagen, og det tør nok antages, at de Inlberetninger, Kultusministeren havde moltaget fra den Side, nærmest have wjort ham uimodtagelig for Præsternes Fremstilling af de nordslesvigske Folkeskolers unaturlige ng ulykkelige Stilling i sproglig Henseende. I Preussen have Provinsregeringrernes og de hoxje Embedsmænds Meninger en $\mathbf{i}$ andre hulturlande ikke kendt, næsten altid afgørendle Betylning.

Fra den 29. Olstober til den 9 . November 1894 holdt Fællessynoden for Hertugdommerne Slesvig, Holsten og Lauenborg sit 6te ordentlige Møde i Rendsborg.

HIer havde Nordklesvigernes valgte Repræsentanter og Prasterne god Lejlighed til at bringe Sprogsagen frem, ng denne Lejlighed benyttedes ogsaa af de forste.

Fra Synodeulvalyet for Tørninglen Provsti og fra over 1300 Repræesentanter for nordslesvigske Kirkesogne var der indsendt Andragender om en Forandring af Sprogordningen af 18. December 1888.

Synodeudvalget for Txrninglen Provsti androg om, at der i de vedkommende Folkeskoler ved Siden af de ugentlige 4 danke Religionstimer matte blive indført et tilstrækkeligt Antal danske Sprogtimer.

I de ovrige Petitioner androges om, at Religions- mulervis ningen der, hror Kirkesproget er dansk, udelukkende maatte gives $\mathrm{i}$ det danske Sprog, og at der $\mathrm{i}$ de nord- 
slesvigske Folkeskoler maatte blive indført mindst 2 Timers: ugentlig Undervisning i det danske Sprog.

Fællessynoden henviste Petitionerne til Petitionsudvalget, der ved Forhandlingerne anganende de nordslesvigske Sprogpetitioner delte sig $\mathrm{i}$ et Flertal paa $7 \mathrm{og}$ et Mindretal paa 2 Medlemmer. For Flertallet blev Prorst Kjer fra Tønder Ordfører, og for Mindretallet Grev SchackSchackenborg.

Flertallets Betænkning sluttede med at anbefale Fællessynoden Overgang til Dagordenen (!).

Mindretallets Betænkningr lød:

"Af follgende Grunde have vi ikke kunnet slutte. os til Flertallets Votum:

1. fordi vi tro, at den næsten fra alle Sider indrommede Skade, Overpræsidial-Anvisningen af 18. December 1888 tilfrjer Kirken, ikke kan forhindres red en streng Udførelse men kun ved en Forandring af selve Anvisningen, og

2. fordi vi ikke ville opfordre Synoden til at desavouere det store Flertal af vore nordslesvigske Præster, der have petitioneret om Sprogtimer.

Derfor beder Petitionsudvalgets Mindretal den høiværdige Synode, at overrække det kongelige lionsistorium Petitionerne med Bon om, at lægge Mærke til den Kendsgerning, at 1329 kaldede Repræsentanter for Kirken i Nordslesvig af kirkelige Interesser holde en Forandring af Anvisningen af 18. December 1888 for paatrængende nødvendig.

H. Schack-Schackenborg. H. Nissen."

Den 8. November stode de to Udvalgsbetænlininger 
som Nr. 1 paa Dagsordenen for Fællessynodens Møde den Dag.

Flertallets Betænkning motiveredes og forsvaredes af Provst Kjer fra Tønder paa en Maade, som vi Nordslesvigere kende saa godt hos visse tyske Gejstlige. Han paastod, at Flertallet ikke kunde indrømme, at det kirkelige Liv i Nordslesvig sygner hen, siden Indførelsen af Sprogordningen af 18. December 1888, og han protesterede imod, at de 2 tyske Religionstimer ere skadelige. Men han maatte indromme, at en frugtbar Religionsundervisning er besværlig efter Sprogordningens Indførelse. Og ligeledes indrommede han, at Sprogordningen kunde vække den Nistanke, at man tilsigter en voldelig Forandring af Kirkesproget $i$ Nordslesvig, ja at en mangelfuld Udførelse af Sprogordningen ligefrem maatte fremkalde en saadan Mistanke. Ogsaa han havde tidligere været af den Mening, at Sprogordningen maatte forandres, og de 77 nordslesvigske Præster havde vist det Mod, at svømme imod Strømmen, tilføjede den nilkæere Kirkens Mand.

Provstens Udtalelser synes ikke $i$ alle Retninger at dække liverandre, men de passe rigtig godt til det personlige Slutningsord, hvormed han tillod sig at encle sit officielle Referat. Det lød:

„Det danske Kirkesprog skal ikke med Vold fortrænges. Tysk og dansk Kirkesprog kunne i det tyske Rige bestaa ved Siden af hinanden. For faa Iger siden holdt vi Missionsfest i Tønder i tysk og dansk Sprog. Til Slutning sang vi i Fællesskab Salmen „Ak, bliv dog med din Naade", tysk og dansk. SaaJedes elske og pleje vi Freden, saaledes ønske vi, at wor Landskirke opbygges i Fred." 
Ja saaledes motiveredes og forsvaredes Flertallets. Betankning, med saadanne Ord mente den gejstlige Ordforer at kunne anbefale den høje Synode at aftixrdige de 1329 kaldede Repræsentanters Petitioner med Orergang. til Dagsordenen!

Nu fik Mindretallets Ordfører Grev Schack-Schackenborg Ordet, og med Alvor og Overberisningens Viagt motiverede og anbefalede han Mindretallets Betrenkning.

Petenternes Besværing over de to tyske Religionstimer kunde maaske give Anledning til at tro, at politiske Grunde havde foranlediget den, mente Greven. Men dette var en Fejltagelse. Han selv kunde ogsaa finde sirg i de. to tyske Religionstimer, thi man kunde jo forklare det dermed, at de unge Nordslesvigere, der senere komme til. tyske Egne, paa Grund af denne Lndervisning vilde vare $\dot{i}$ Stand til ogsaa paa tysk at kunne udtale sig om kirkelige Ting. Men man hørte næsten altid kun den Forlibaring, at Hensigten med de to Timer var, at de unge fuldkommen skulde kunne folge en tysk Gudstjeneste. Af denne Forklaring havde næsten alle Nordslesvigere sluttet, at den egentlige Hensigt med de to tyske Religionstimer var, $^{\text {, }}$ med Vold at germanisere den nordslesvigske Kirke.

"Jeg behcrsker det tyske Sprog tilstrækkelig til at kunne forstaa en tysk l'rodiken,“ fortsatte Greven, "men skulde jeg nogensinde opleve, at der i min Hjemern bler prædiket tysk, saa vilde Opbygggelsen for mig falde bort. Guds Ord i Nodersmaalet gaar ganske anderledes til Hjertet. Pintseunderet beviser, at Forkyndelsen skal ske i Modersmaalet, og den tyske Reformator liar jo for den lutherskeKirke tilbageerobret Forkyndelsen i Modersmaalet. Ogsaa 
vi Nordslesvigere ville beholde Forkyndelsen af Guds Ord i Mod ersmaalet.

Bliver Religionsundervisningen udelukkende givet paa Tysk, saa vil dette øve en stor Indflydelse paa Livet i Bønnen. I tunge Tider findes Ordene til en Bøn let. Men der gives Tider, hvor vi ma tvinge os til at bede. Dersom Børnene i Nordslesvig kun have lært tyske Bønner, saa ville de $\mathrm{i}$ gode Dage let glemme at bede. Det kristelige Liv kan bestaa uden Gudstjeneste, men det kan ikke bestaa uden Bøn. Og Spørgsmaalet: hvad bliver det til med Kirken og det kristelige Liv, naar Sprogordningen bliver uforandret bestaaende? har netop foranlediget de nordslesvigske Menigheders Repræsentanter til at fremhæve det forste Petitum i deres Petitioner.

Byogres der en Mur, saa behgves først og fremmest et godt Fundament. Er der ingen Stene til Fundamentet, saa benyttes de til Muren bestemte Stene til Fundamentet, og til Muren er der saa ikke det nødvendige Materiale. Muren er den danske Religionsundervisning, Sprogundervisningen er Fundamentet. Hvor der gives dansk Religionsundervisning, har man hidtil ikke kunnet undvære Sprogundervisningen. Men vi ønske, at Sprogundervisningen ikke maa gives sammen med men ved Siden af Religionsundervisningen.

Naar Børnene have forladt Skolen, glemme de i danske Omgivelser det Tysk, de har lært i Skolen. De skrive atter Dansk, men med tysk Orthographi, og jeg har ofte set Breve, der vare fuldstændig uforstaaelige. Heri ligger en stor Fare for den konfirmerede Ungdom. Den farligste Tid for Børnene er den, da de forlade Hjemmet. Brevslirivningen forbinder dem dog med Hjemmet og 
beskytter dem imod mange Farer. Men kan de ikke skrive deres Modersmaal, saa bliver Samlivet med Hjemmet besrærliggjort, og deri ligger en stor Fare.

Ifølge Overpræsidial-Anvisningen kan der indføres udelukkende tysk Religionsundervisning i de nordslesvigske Sogne, hvorfia der ansøges derom. Paa hvad Maade Ansøgnninger blive til, er noksom bevist i denne Synode. Med Hensyn til Ansøgningerne om tysk Religionsundervisning kommer desuden det i Betragtning, at danske Undersaatter af Frygt for Udvisning hyppig underskrive disse Ansøgninger.

At den nordslesvigske Kirke har lidt Skade ved Sprogordningen, er almindelig indrømmet. Præsterne ville mærke det ydermere, naar først de Børn, der ene ere underviste efter den nævnte Anvisning, møde til Konfirmationsundervisning. Men allerede nu har Majoriteten af de nordslesvigske Præster udtalt sig for en Forandring af Sprogordningen.

Det store Flertal af disse Præster er tysk-national sindet. Deres Petition til Ministeren fremgik ene $g$ alene af en indre Pligtfølelse. Da disse 77 Præster imidlertid ikke holdt det for formaalstjenligt, at tage de verdslige Repræsentanter for Kirken med, have disse fundet sig foranledigede til, at frembære deres Ønsker $i$ de foreliggende Petitioner.

Mine Herrer, de kende ikke Forholdene i Nordslesvig saa nøje, at de ligeoverfor Præsternes Flertal, ligeoverfor næsten alle Lægrepræsentanter for den nordslesvigske Kirke og ligeoverfor den store Majoritet af de nordslesvigske Medlemmer af denne Synode tor udtale, at de i Petitionerne udtalte Ønsker ere ubegrundede. 
Vi bede ikke om, at de udtaler dem for disse Petita, men vi onske, at Synoden officielt bringer dem til Konsistoriets Kundskab. Konsistoriet kan da undersøge dem. Vi ville kun gøre vor Pligt, saaledes som vor Kirkes Grundlov og vort i denne Synode aflagte Løfte paalægge os det. Vi ville efterkomme vor Pligt saaledes, at vi paa den yderste Dag kunne forsvare det for Vorherre. For Resultatet ere vi ikke ansvarlige. Naar vi gøre vor Pligt, kunne vi overlade Udfaldet til Vorherre og stole paa, at han ogsaa fremdeles vil beskytte sin Kirke i Nordslesvig." Holsteneren Pastor Harder fik Ordet og yttrede blandt Andet:

„Jeg er ligesom Synodemedlemmerne fra Nordslesvig af den Mening, at Børnene fuldstændig maa beherske det Sprog, paa hvilket Religionsundervisningen meddeles dem. Jeg er overbevist om, at de 77 Præster har ladet sig lede ene og alene af Interessen for Befulkningens religiøse og kirkelige Liv. Provst Reuter, der stanr i Spidsen for hine 77 Præster, er en god tysk Mand.“

Alligevel anbefalede denne gejstlige Herre Synoden, at stemme for Overgang til Dagsordenen.

$\mathrm{Nu}$ fik Synodemedlem, Gaardejer Hans Nissen fra Viby paa Als, det andet Medlem af Petitionsudvalgets Mindretal, Ordet. I en inderlig Tilslutning til den grevelige Ordførers bestemte og indtryksfulde Tale, udtalte den frie Bondemand sig paa sin jærne men ligeledes af inderlig og dyb religiøs Overbevisning prægede Maade sin Mening om de i Petitionerne fremsatte Ønsker angaaende den nordslesvigske Befolknings Hjertesag.

Hans Nissen sagde:

„Mine højtærede Herrer! Jeg staar paa de 1329 
Petenters Standpunkt, og, som jeg antager, saaledes paa vor evangelisk-lutherske Kirkes Grundvold. Paa første Pintsedag har den hellige Aand for Alverden givet tilkende, at Evangeliet skal bringes Folkeslagene paa deres eget Tungemaal. Ved den lutherske Reformation er denne Grundsætning atter kommen til sin Ret.

Overprasidialanvisnigen af 18 . December 1888 har dog forladt dette Princip, paa den ene Side ved den Bestemmelse, at de nordslesvigske Børn kun tildels maa undervises i Religionen paa deres eget Sprog, og paa den anden Side ved, at man ikkke giver Børnene Undervisning i det danske Sprog, hvoraf atter folger, at selve de danske Religionstimer ikke fuldt ud medfore den tilsigtede Nytte.

Petitionsudvalgets Majoritet paastaar nok, at det dobbelte Religionssprog kun kan fremme Børnenes religiøse Erkændelse, men de 77 Præster paastaar i deres Andragende, at Skolen med Hensyn til Religionsundervisningen ikke yder det, hvad der efter de almindelige Bestemmelsers $\$ 15$ betegnes som dens Opgave. At dette maa indvirke uheldig paa det religiøse og sædelige Liv, er klart.

Efter min Opfattelse ligger den største Anstødssten par et andet Sted. Indforelsen af de tyske Religionstimer kan vi kun betragte som et Skridt til Kirkens Germanisering.

Denne Opfattelse bestyrkes ogsaa af Bestemmelsen i Anvisningens $\$ 5$. Her forordnes nemlig, at de kongelige. Skoleinspektører - og i de allerfleste Tilfæelde er det jo Præsterne - i "Samkvem med Børnene skulle benytte sig af det tyske Sprog og agte paa, at dette ogsaa mere og mere bliver Tilfældet med Børnene i deres indbyrdes Samliv. " 
Naar dette ikke er Germanisering, saa ved jeg sandelig ikke, hvad Germanisering er. Altsaa Germanisering ved Gejstligheden, rigtignok i deres Egenskab af Skoleinspektører, af Statstjenere, men dog ved de samme Personer, der staa i Menighederne som Guds Tjenere.

Forestil dem en Gang, mine Herrer, at en Præst $i$ sin Egenskab af Sjælesørger aflægger Besog hos en Familie i sit Sogn. Med Forældrene er han nødt til at tale dansk, da disse ikke forstaa tysk, og med Bornene skal han som Skoleincpektør tale tysk. Tror de, at Præsterne under saatanne Forhold kunne virke med Velsignelse i deres Menighed?

Mine højtærede Herrer! I Nordslesvig hersker en Nødstilstand, en kirkelig Nødstilstand, hvis Rælikevide maaske kun vi, der daglig have den for Øje, rigtig kunne fatte. Petitionsudvalgets Flertal siger jo ogsaa, at den (Nødstilstanden) er notorisk. Det glæder mig, at jeg ogsaa er i Overensstemmelse med Flertallet deri, at den religiøse Ophidselse hos os er fremkaldt af Anvisningen af 18. December 1888.

Forresten holder jeg det for ikke korrekt af Flertallet, at det af Petenterne fordrer et Bevis for, at det religisse Liv hos os sygner, da det selv benytter Petenternes Vidnesbyrd som Bevis for starke kirkelige Misligheder.

Men naar Nødstilstanden er notorisk, saa maa den afljwlpes. Angaaende Midlet hertil lar jeg desrærre ikke liunnet slutte mig til Flertallet. Det er jo muljgt, at den kongelige Regering for Tiden alvorlig tilstrober at pleje oor forbedre den danske Lndervisning; en bestemt aaben Erklæring $i$ den Retning fra den hxje kongelige Regering foreligger ikke, saavidt jeg ved. 
Vi frygte ikke saa meget for en voldelig Forandring af vort Kirkesprog, i det Mindste ikke i dette Aarhundrede; men sér vi paa Fortiden, saa kan vi ikke værge os imod den Rngstelse, at Kirken skal germaniseres med List. Saalænge Anvisningen of 18 . December 1888 bestaar uforandret, formaar jeg ikke at indse, at den kan gennemføres uden Germanisering. Ilkkun ved en Forandring kan det Saar, den har tilføjet Kirken, læges.

Naar de, mine Herrer, virkelig ville bidrage til at afhjælpe Nødstilstanden, naar de ville berolige de nordslesvigske Menigheder, naar de ville forbarme dem over de nordslesvigske Fædres og Mødres Samvittighedsnød, hvis Børn det gælder, og jeg vel, at de har Villien, saa stem for Mindretallets Andragende!"

Disse indtrængende Ord af den nordslesvigske Bondemand, denne af dyb religiøs Sorg prægede Tale af den om sin Sags Renhed af Hjertens Grund overbeviste Hædersmand, fulgtes af en alvorsfuld Præstemands indtrærgende Henvendelse til Synoden om at støtte Mindretallets Andragende.

Det var Pastor Claussen af Dybbøl, der fik Ordet og aflagde folgenile Vilnesbyrd:

„Naar jeg tager Ordet, saa sker det, for at aflægge et personligt Vidnesbyrd. Jeg er en af de 77 Præster, der $\mathrm{i}$ en Petition have henvendt sig til Ministeren. Uden at tilegne mig Petitionernes Indhold, træder jeg ind for Mindretallets Petitum, fordi der i dette tages Hensyn til vor Stilling. Det er ikke let at tage Ordet $\mathrm{i}$ demne Sag, der næsten er haabløs. Vi blive derved udsat for alle .Slags Mistydninger, men "uden Frygt og uden Gysen“ tager jeg dog Ordet $\mathrm{i}$ denne vigtige Sag. Vor Ungdoms 
Undervisning i Modermaalet er en Helligdom, betydningsfuld for vor Landskirke, for Menighederne og Ungdommen selv. Tillad mig nogle historiske Kommentarer:

Overpræsidialanvisningen udstedtes i 1888; den Gang levede vi i Fred. Med Tak erkænder jeg, at Anvisningen har ladet os beholde de 4 Timer Religionsundervisning paa Modersmaalet, som vi kan fordre. Alligevel maa vi slutte os til den Anskuelse, at Anvisningen indeholder en Fare for vor Kirke. Derfor gik vi til vor kirkelige Øvrighed, og afgjort tysk-nationale Præstei til Overpræsidenten, for at forebringe vor Betænkning. Ogsa Kirkeforstanderskaberne have henvendt sig til Konsistoriet. Af Konsistoriet modtoge vi det Svar, at vi, da Overpræsidialanvisningen ikke kunde forandres, maatte gøre alt muligt for at afværge den Fare, vi gjorde opmærksom paa. Derpaa har Sagen været til videre Forhandling i de nordslesvigske Synoder. Tilsidst have vi 77 Prrester henvendt os til Kultusministeren med vor Petition, i hvilken vi henviste til den Skade, som allerede er sket og altid vil brede sig mere, og bade om 2 Timers dansk Syrogundervisning.

At Skaden hidtil ikke er storre, liggrer tildels i, at vi Præster troligen have udført vort Arbejle. Videre vil jeg meddele: Vort Folk er opfyldt af Sorg, fordi det ser sit Modersmaal truet. Denne Sorgs Berettigelse finder allevegne Udtryk, f. E. ved Katekisationerne, ved hvilke Birnene langt fra kunne følge saa godt med og svare saa godt som tidligere. Mine Konfirmantler kunne ikke mere som tidligere selvstændig nedskrive Kontirmandundervisningen, jeg naa bede dem om at afskrive samme, og alligevel grre de mange Fejl. Ligesom det er umuligt for Born med plattysk Tungemaal at folge en Religions- 
undervisning paa det bojtyske Sprog uden Sprogundervisning, saaledes er det ogsaa umuligt for Born, der hjemme kun tale Platdansk, uden Sprogunderrisning at folge Religionsundervisningen paa Dansk. ${ }^{*}$ Det danske Sprog ma bevares for Bornene, det er et lifligt Sprog, et Sprog, der har en stor Literatur. Men skal dette ske, saa maa de danske Religionstimer blive barret af Lndervisning i Skriftsproget.

Ogsaa vor Landskirke trues af en stor Fare. Gamle Folk hente deres Opbyggelse ved Siden af Kirken af gamle danske Pradikensanilinger. Bliver nu den danske Gudstjeneste formindsket, saa søge de Opbygurelse paa anden Maade, og Faren for en Udtrædelse ligrrer nær. Jeg er ingen Profet og ikke Søn af en Profet, men jeg boer hos mit Folk og elsker det, rlet ganske Folk, ogsaa Nordslesvigerne. Derfor træder jeg bedencle og advarende rem for Synoden, at man maa bevare sig et Hjerte ogsaa for Nordslesvig or vertage Minoritetens Petitum."

Med alvorsfuld Taushed havde hele Synoden fulgt Pastor Claussens Vidnesbyrd, men alligevel fulgte Majoriteten ikke hans indtrangende Opfordring.

Provst Kjer uitalte nok, at han agtede Pastor Claussens Vidnesbyrd, og at han gav Nissen-Viby Ret $i$, at en notorisk Nodstilstand var tilstelle i Nordslesvig.

Pastor Lühr fra Ditmarsken erklærede sig for Indførelsen af danske Sprogtimer, men Generalsuperintendent Kaftan afyav den Erklæring, at han i sit Hjerte ikke narede Sunr af F.jendskab imod det danske Spros, men dog var kommen til det Resultat, at han tjente Kirken i

*) Pastol ('laussen har naturligvis af Hensyn til den hos Tyskerne giengse Talemaade: "platdansk og hojulansk" benyttet Beternelsen ,platilansk" for det danske Folkesprogr i Noriklesvig. 
Nordslesvig bedst ved at stemme for Majoritetens Petitum, der wik imod Andragendet om dansk Sprogundervisning i Menighederne med dinsk Kirkesprog.

Overprædisialraad Hagemann udtalte sig bestemt imod Ninoritetens Andragende og paastod, at det ogsana var Statsministeriets Standpunkt. Hans Tale vidnede om preussisk Ukendskab til Forholdene og Tildragelserne Nordslesvir, og ofte lod den som en Gentagelse af de hadefulde Beskyldninger, en vis Klasse tyske Avisskrivere pleje at udslynge imod den nordslesvigske Befolkning. Men den ivrige Regeringsrepræsentant høstede intet Bifald hos Forsamlingen. Han blev tildels imødegaaet af Generalsuperintendent Kaftan og Pastor Wolf fra Varnas, oy Grev Schack tilbageviste hans haarde Beskyldninger paa en saa bestemt Maade, at den danskfjendtlige Overpræsidialraad saa sig nødsaget til at give sine Ord en mildere Form.

Et Andragende om Afslutning af Debatten veltoges nu, og red relve Afstemningen stemte kun 23 Synodemedlenmer for Minnritetens men 66 for Majoritetens Andragende.

Saaledes behandlede Hertugdommernes Fællessynode Nordslesvigernes Andragende om nogle danske Sprogtimer i de Skoler, hvor Religionsundervisningen og Kirkesproget er Dansk! En Forsamling af 90 Medlemmer, hvoraf henimod Halvdelen vare gejstlige Herrer! Ikke faa af de Herrer, der stemte merl Majoriteten, have i sin Tid været med til i horje Toner at fordsmme det danske Sprogreskript, hvorefter der i Aarene mellem 1851 til 1864 i de saakaldte blandede Sogne (Sogne med dansk or tysk Omgangsiprog) i Mellemslesvig indfortes dansk Skolesprog med 4 ugentlige tyske Sprogtimer. Men nu handlede de 
i Overenstemmelse med det tyske Ord: „Ja, Bauer! das ist ganz was Anders."

Hvad agte de syvtisyv Praster nu at gøre? spurgte Nordslesvigerne. Man turde jo ikke tro andet, end at de Herrer Præster alle havde ment det ærligt og alvorligt med deres Forlangende om dansk Sprogundervisning, thi de havde jo alle erklæret, at deres Samvittighed havde været Drivfjederen for deres Henvendelse til Konsistoriet, Regeringspræsidenten og Ministeren. Deres Ordfører, den niyndige Provst Reuter i Broager havde endog udtalt: "Reliyionsundervisningen vil være lig Nul for de dispenserede Børn, hvis Anvisningen af 18. December 1888 opretholdes."

Men blandt de syvtisyv fandtes ikke faa, der furst og fremmest følte sig som Statstjenere og paa preussisk Vis forstode at følge et Vink fra den verdslige Regering, og de faldt efterhaanden fia.

„Børnene maa behandles som Døvstumme!“ forkyndte Kredsskoleinspettor Mosehuus fra Aabenraa, og mangen en Gudsmand bøjede sig for Korporalstokslæren og opgav Modstanden imod det danske Modermaals Tilsidesættelse i Skolen par det religiøse Livs Bekostning

Paa de nordslesvigske Provstisynoder i 1895 og 96 blev Sprogsagen atter og atter draget frem af de folkevalgte Reprosentanter, men Præsternes Tilslutning blev svagere og svagere. Haarde Ord maatte de tilbagevigende Præster høre af deres Kolleger blandt Lægmændene, og det skete, at de i Taushed hørte paa alvorsfulde Bebrejdelser. Men det skal siges til Ros for de nordslesvigske Præster, der forblev tro imod deres Opfattelse af Sproganvisningen af 18 . December 1888 , at de mere og mere. 
aaben $0 \mathrm{~g}$ ærlig bekende $\mathrm{og}$ vise, at det er en virkelig Samvittighedssag for dem at arbejde for Indførelsen af danske Sprogtimer i de nordslesvigske Folkeskoler.

Men skulde den preussiske Regering deraf, at over en tredie Del af de syvtisyv nordslesvigske Præster af Hensyn til deres Stilling som Statsembedsmænd og fordi de bleve skuffede $\mathrm{i}$ deres Forventning om Medgørlighed hos Regeringen i Sprogsagen have trukket sig mere og mere tilbage, slutte, at der i Sprogkampen efterhaanden ogsaa vil vise sig Slappelse hos en Del af den nordslesvigske Befolkning, saa vil den blive grundig skuffet. Sprogsagen er en Hjertesag for den nordslesvigslie Befolkning, og selv de nationalt mindst udviklede føle, at der i sproglig Henseende fra tysk Side oves en Uret, der er saa indgribende, at den forstyrrer Kulturudviklingen or Aandslivets Hojjning i den Grad, at det i saa Henseende maatte gaa sørgelig tilbage i Nordslesvig, hvis der ikkc fra Befolkningens Side blev bragt Offer paa Offer for at forhindre dette. Men den, der tvinger et Folk til Aar ud og Aar ind at bringe Offer paa Offer, hvor det unde naturlige Forhold vilde vere unødvendig, er ikke Folkets Ven og bliver det aldrig.

I „Sønderjydske Aarbøger“ for 1894, Side 9, hedder det: „En Bøjning henimod en Udtrædelse af Statskirkeu og Sanmenslutning til frie Menigheder med selvvalgte Præster, gjorde sig ogsaa gældende i 1893 or synes at være i stadig Fremgang."

Dette Ord har fundet Bekiæftelse i Udviklingen af det religiøse Liv i Nordslesvig i 1894 til 96, navnlig med Hensyn til Sammenslutningen til frie Henigheder med selvvalgte Praster. Og Pastor Claussens Ord paa Folles- 
synoden om den Fare for Landskirken, at Folk kunde søge Opbygrgelse udenfor den, har vist sig at have været berettiget.

Istedetfor tidligere to Frimenighedspræster har Nordslesvig i de sidste 3 Aar haft 3 , og en fjerde ja rimeligvis ogsaa en femte vil snart firlge efter. Dertil kommer, at denne Bevægelse har bredt sig fra det restlige Nordslesvig til det astlige, og snart vil den spænde sig over det hele og omslutte alle, der fole, at kun paa den Miade kan den kirkelige Nødstilstand aflijælpes.

Disse Frimenigheders Gudstjenester holdes endnu i Forsamlingshluse og private eller offentlige Lokaler, men ogsaa i saa Henseende tegner det til en Forandring.

Paa Bakken red Borlund, Bovlund Bjærg kaldet, omtrent lige langt fra (ysterwsen og Vesterhavet, ligesom ogsaa omtrent lige langt fra Kongeaaen og det danske Sprogs faste Grænse imod syd, milt i Nordslesvig, er der af den gamle Frimenighed for Bovlund og Omegn rejst et Gudshus, vidt synligt fra alle Sider. Det er en smuk Kirke med Langskib, Kor, Korrunding og et slankt med spir forsynet Taarn.

Det var Menighedens mangeaarige og nidkære Præst, den afholdte og i vide Kredse kændte Pastor L. B. Poulsen, der fattede Tanken, og Menighertens xldste Medlem, den i 1895 aftesde, over hele Nurdslesvig som en alvorsfuld og fremragende Patriot kenlte Gaardejer Bunle Refslund, greb Tanken med inderlig Glæde og stillede sig i Spidsen for dem, der paatoge sig Arbejdet for dens Virkeliggorelse. Ved frivillige Bidrag isæar fra den frie Menigheds egne Medlemmer og frä Venner rundt onkring i Nordslesvig indkom der nu Bidray til et Beløb af ontrent 16,000 Mk. Fra Frimenigheder norden Aaen indlob der Gaver, saasom 
et Alterbord, et Par Alterlysestager, en Granitdøbefont, en Altertavle, en Klokke og mange værdifulde Udsmykningsgenstande. Ned Iver toges der fat paa Byggearbejdet, og allerede i Eftersommeren 1896 var den forste Frimenighedskirke i Nordslesvig fardig til at tages i Brug.

De preussiske Myndigheder have altid set skævt til alle Forsamlinger og Møgler; den danske Befolkning holder rundt omkring i Nordslesvig, 0gsaa til kristelige eller kirkelige Møder og Forsanlinger. Frimenighedernes Gulstjenester ma anmeldes som offentlige Møder, oo en Gensdarm plejer at overvaage Gudtjenesten fra Begyndelsen til Slutningen. En Tid lang forbøde Undermyndighederne, at Gulstjenesten i Bovlund Frimenighed afholdtes i den egentlige Sirndagstid fra Kl. 10 Formidding til 4 Eftermidlag, men Pastor Poulsen klagede til Kammerretten i Berlin, or snart kunde han atter aflonlde Gudstjeneste om Formiddagen. Men Genslarmen har fremileles Lov at overvaage Guilstjenesten, ogr det er jo et talende preussisk Billede, at tanke sig en preussisk Gensdarm med Pikkelhue paa, stillende sig ved Silen af Alteret eller Prælikestolen i Frimenighedens Forsamlingssal, med morkt Blik betragtende enhver, der træder ind i Salen, or stram ng afimalt forlade den, naar Gudstjenesten er forbi og Menigheden gaar hjem. I offentlige, politiske Mrsler kan man ranne sig til Politiets Nærværelse, ja man kan blive saa vant til at se en eller to Uniformer or Pikkelhuer ved saadanne Muder, at man ligefrem savner dem, naar de tilfxldigris ikke strax red Indets Begyndelse eller for en kort Tirl unler Msslet ikke vise sim for en. Men under r'n Gudstjeneste at skulle blive overvaaret af en preussisk Pikkelhuemand, det kan ikke enlver vaenne sig til. 
Kirken i Bovlund var altsaa færdig til at tages i Brug, og der anmeldtes en Forsamling $i$ den til den 19de September 1896. Men nu gjorde Myndighedernegældende, at Kirken ikke maatte tages i Brug, inden der var indhentet ministeriel Tilladelse dertil, og den anmeldteForsamling forbødes.

Et klogt Hoved havde nemlig fundet en gammel dansk Lov eller Forordning, der for længe siden var gaaet $i$ Glemmebogen, men nu toges frem for at blive anvendt imod Bovlund Frimenighed. Ifølge denne Lors Bestemmelse skal der af Ministeriet gives Tilladelse til Afholdelse af Gudtjeneste i særlig dertil opførte Bygninger, og denne Tilladelse havde man ikke ansøyt om. Der blev naturligvis strax ført Klage over Forbudet af den aumeldte Forsamlings Afholdelse, men endnu er der ikke truffen nogen Afgørelse $i$ denne Sag, og Kirken paa Bovlund Bjærg staar den Dag i Dag uden at blive benyttet. Men ogsaa denne Prøvelsestid vil far en Ende, og den vil visseligen ikke skade det frie Menighedsliv.

Imidlertid bygges der en anden Frimenigheds-Kirke ved Haderslevfjord, og ogsaa dette Gudshus vil snart staa som et Vidnesbyrd om, at den danske Befolkning $i$ den nordøstlige Del af Nordslesvig ogsaa har Evne og Villje til at afhjælle den kirkelige Nødstilstand, som Magthaverne have fremkaldt i vor fra gammel Tid som kirkeligsindet bekendte lille Landsdel.

I Haderslev og Haderslev Omegn tiltog i de sidste Aar Trangen til at høre Guds Ord forkyndt i Modersmaalets rene Toner og af Nænd, der forstaa Folkets inderste Hjertelængsler, sala Præst og Menighed blive ét. Snart 
renedes man da ogsaa om at hidkalde en Mand, om hrem man troede, at han i alle Maader nærmest kunde afhjælpe denne Trang. Man skrev til Amerika, til den der som Ordets ivrige Forkynder virkende Landsmand Pastor R. Thomsen, og Thomsen kom. Nu begyndte Pastor Thomsen at holde Gudstjeneste med en fri Menighed i private og offentlige Lokaler i Haderslev og Omegn, og Ønsket om at kunne samles med deres Fripræst $i$ en rigtig Kirkebygning bredte sig blandt de mange, der sluttede sig til ham. Man begyndte med at samle frivillige Bidrag til for dem at kunne opføre et Gudshus, og disse Bidrag flød saa rigelig, at man snart kunde begynde med at bygge en Kirke, der om ikke længe vil staa færdig, til at tages i Brug, ligesom Bovlund Frikirke.

Det er dog ikke alene i disse Egne, hvor det frie Menighedsliv har gjort sig saa stærkt gældende, saa man begyndte med at bygge sig selv Kirker, at det nordslesvigske Folk føler den kirkelige Nødstilstand; uej, overalt mærker man denne Følelse, der vel paa mange Steder endnu er en Understrøm, men snart kan vise sig som en, ogsaa den store Masse med sig rivende aandelig Bevægelse.

Vore tysksindede Præster og deres Foresatte have i Almindelighed kun meget lidt Øje for, hvad der baader den af dem repræsenterede Statskirke bedst. Derfor sker der hos os Ting, der ere aldeles uforstaaelige for Folk, der ere af den Mening, at Kirkens Tjenere og al Øvrighed bør ove Fordragelighed og Mildhed i deres Optræden ligeoverfor dem, for hvis Skyld de ere til og som de ere satte til at lede og styre saaledes, at de vindes istedetfor at frustødes.

En ejendommelig Fremgangsmaade af de kirkelige 
Myndigheder maatte Kirkeældste Callesen i Lerskov i Aabenraa Provsti lide under i 1895. Hans Datter var forlovet med en Mand, der er udtraadt af Statskirken og hører til en nordslesvigsk Frimenighed. Da nu Bryllupet sliulde staa, blev det holdt i Callesens Hjem, og en Frimenighedspræst forrettede Vielsen. Vore Frimenigheder høre, som bekendt, ligesom vore Statsmenigheder til den lutherske Kirke. Alligevel tog Stedets Statskirkepræst af denne Vielse i Callesens Hjem Anledning til, at erklære Callesen for uskikket til at væere Kirkeældste i en Statskirkemenighed, og Provstisynodeudvalget sluttete sig i $\sin \mathrm{Ma}-$ joritet til Præsten. Callesen, en kirkeligsindet $0_{g} \mathrm{i}$ sit Sogn som overalt, hvor han er kændt, meget agtet og anset Mand, protesterede imod sin Afsættelse som Kirkexldste. Dette nyttede dog ilike, han fik intetsteds Medhold hos de kirkelige Myndigheder, endskøndt man ikke kunde fremføre andet imod ham, end at han havde vist Geitfrilied mod sin Datter paa hendes Bryllupsdag. Er derRimelighed for, at en saadan Fremgangsmaade vil gavne Statskirken og skade Frimenighederne? I Ien, der tror det, tager visseligen fejl.

Den nordslesvigske Presse ledes fremdeles af Mænd, cler trofast kæmpe red Befolkningens Side for Modersmaalets og Nationalitetens Berarelse, altid staaende paa de udsatte Poster, saa Modstanlernes Angreb særlig rette sig imod dem. Idelige Presseprocesser og Pengebøder; ja meget ofte Frngselsstraffe af langere Varighed var ogsaa i Aarene 1894 til 96 den $\Lambda$ nerkændelse, vor Presses Repræsensanter fik af de preussiske Domstole for de frejdige Ord, de til enhver Tid lod lyde under Kampen.

Blandt Presseprocesserne $i$ de sidstforlglbne tre Aar 
have to vakt sarlig Opmærksomhed selv langt ud over Nordslesvigs Grænser. Den ene var Processen angaaende Anvendelsen af vor Landsdels gamle Navn Sønderjylland, og den anden var Processen angaaende Benyttelsen af den gamle danske Talemaade: „For en Ordens Skyld“.

Navnet Sønderjylland, der fra Arrilds Tid er bleven brugt for vor Landsdel, det gamle danske Kronland imellem Kongeanen og Ejderen, som indtil vore Dage benyttedes Side om Side med Betegnelsen Hertugdømmet Slesvig, dette Navn er nu forbudt og maa ikke bruges af os Nordslesvigere, hverken i Skrift eller Tale. Mon der gives nogen Kulturstat udenfor Preussen, hvor et lignende Forbud existerer? $O g$ mon Preusserne tro, at vi Nordslesvigere nu skulde glemme det gamle Navn Sønderjylland og forsømme at bringe til kommende Slægters Kundskab, at dette Navn er det historiske, det oprindelige Navn for Landet imellem Kongeaa og Ejder? Hvis saa er, da tage de visseligen Fejl.

Nen de tage jo tidt fejl, og de toge ogsaa fejl, da de udlagte Talemaaden „For en Ordens Skyld“ som betydende: for at faa en Orden. En preussisk Amtsiommer harde givet den nævnte Talemaade denne Betydning, en Tolk ved en preussisk Landret paastod, at Amtsdommeren kunde have Ret, og et ikke navngivet Akademi (?) havde afvivet det Skøn: Ordene „for en Ordens Skyld" betycle forst og fremmest "der Ordnung wegen“, men kunne sproglig lige saa korrekt betyde "eines Ordens wegen“. Det nyttede ikke, at sagkyndige Mænd for Retten afgave den Erklæring, at det paaklagede Udtryk kun kan betyde „af Hensyn til Skik og Brug “; to Medarbejdere ved „Flensborg Avis" bleve idømte Fængelsstraffe for at have benyttet 
det nævnte Udtryk i en Meddelelse om en tysk Fest, fordi en tysk Amtsdommer følte sig fornærmet i Meddelelsen ved det nævnte Ord. Det hjalp heller ikke, at Præsidenten for det kongelige danske Videnskabernes Selskab i Kjøbenhavn, Julius Thomsen, at Professor i sammenlignende Sprogvidenskab ved Kjøbenhavns Universitet, Vilhelm Thomsen, at Professor i de nordiske Sprog ved København Universitet, Ludv. Wimmer, at daværende Rektor ved samme Universitet, Zeuthen, at en Række andre danske Autoriteter i sproglig Henseende udtalte sig bestemt for de anklagedes Forklaring af det benyttede Udtryk, og at over 2000 ansete nordslesvigske Mænd erklærede, at de vare villige til for Retten at bevidne, at man i Nordslesvig ikke forstod andet ved Ordet „For en Ordens Skyld“ end "af Hensyn til Skik og Brug". De to Journalister maatte afsone de Fængselsstraffe, de vare blevne idømte paa Grundlag af et sprogligt Skøn, hvis Indhold var absolut falsk.

Den danske Presse er naturligvis ogsaa udsat for Anigreb fra den tyske Presses Side, og da den sidstes Ledere og Nedarbejdere her i Nordslesvig ikke netop kunne roses for at holde paa god Tone i deres Organer, saa er det ikke sjældent, at ogsaa grove personlige Fornærmelser fremkomme imod den danske Befolknings fremtrædende Mænd. Det er sket, at der er bleven rejst Klage af danske Mænd imod tyske Avisskrivere for personlige Fornærmelscr, og de tyske Avisskrivere ere ogsaa adskillige Gange blevne idømte Pengebøder, ja, i et enkelt Tilfælde endog en ret betydelig Pengebøde. Men saa er det ogsaa sket adskillige Gange, at disse "Ritter von der traurigen Gestalt" have ansøgt om Benaadning og have 
opnaaet enten fuldstændig eller delvis Fritagelse for den idømte Straf. Og saadanne Herrers jou:nalistiske Produktioner skulde virkelig betyde noget $i$ en national Kamp som den, vi føre? Nej, og atter nej! det tyske Folk maatte jo tabe Agtelsen for sig selv, naar det vedblivende vilde lade sig føre bag Lyset af disse Lejesvende. Men Presseforholdene hos os belyses dog ogsaa af saadanne Udslag af tysk Kampmaade.

Ogsaa Udgiveren af "Sprogforeningens Almanak“, M. Andresen, paaførtes der en Presseproces for en Fortælling i Almanaken, men Straffen blev dog, efter hrad nordslesvigske Redaktører er vant til, ikke nogen betydeligere Fængselsstraf.

Blandt Forseelserne imod Lovene findes der i den preussiske Stat en ejendommelig Kategorie, der kaldes "grov Uorden". I Nordslesvig er denne Kategorie i de sidste Aar hyppig bleven eftervist.

Da en nordslesvigsk Landmand om Aftenen paa Danmarks Konges Fødselsdag satte Lys i sine Vinduer, bemærkedes dette ogsaa af hans tysksindede Nabo. Denne Nabo blev senere, da Landmanden maatte møde for Retten, som anklaget for at have begaaet "grov Uorden“, tilkaldt som Vidne, og nu udsagde Tyskeren, at han hin Aften havde set Lys i den anklagedes Vinduer, at han havde æryret sig derover og derpaa var gaaet i Seng. Dette naive Vidnesbyrd var et Bevis for, at den anklagede virkelig havde gort sig skyldig i „grov Uorden“, og han blev idømt en Pengebøde. Men antage Preusserne, at Nordslesvigerne paa den Maade ville lære at glemme den danske Konges Fødselsdag, da tage de ogsaa her fejl.

Oysaa Pressens Repræsentanter bleve i de sidste Aar 
anklagede for at have gjort sig skyldige i "grov Corden", ligesom flere Privatfolk. Et Par af de silste, fordi de havde udstillet Handelsvarer med Dannebrogsfaner paa.

Fra Tid til anden, tilsyneladende altid med visse Mellemrum, udvistes der i de sidste Aar en Masse danske Undersaatter af Landet. Saaledes $i$ den første Halvdel af 1894 over 100, og henimod Slutningen af samme Aar fik paa en Gang en Snes kongerisk-danske. Mejerister, der havde Ansættelse ved større Mejerier i Nordslesvig, Befaling til at forlade Landet.

Berømte danske Skuespillere fra det kongelige Theater i København, der af en nordslesvigsk Theaterdirektør var engageret til at spille nogle Aftener i Haderslev, bleve strax ved deres Ankomst til nævnte By udviste af Lanclet, endskondt Politiet havde faaet forelagt alle de Stykker, der agtedes opførte, og ikke havile haft noget at erindre imod dem. Men en preussisk Udvisningsordre forhindrede, at Befolkningen i navnte By or Omegn eller noget andet Sted i Nordslesvig kom til at nycle en ualmindelig kunstnerisk Opforelse af Skuespil paa Modersmaalet, og de danske Kunstnere bleve, uden i mindste Maade at have forset sig imod Landets Love, expederede over Landets Grænse.

Fru Elfride Fibiger fra København blev det i 1896 forbudt, at holde et Foredrag i Haderslev om "Kivindens Betydning for Hjemmet". Hun havde allerede averteret Foredraget, da hun iforvejen havde indhentet den haderslevske Borgermesters Tilladelse dertil, men saa kom der pludselig et afgorende Forbud, og det aldeles upolitiske Foredray maatte aflyses.

Men ikke blot Skuespil og Foredrag af kongerigske 
Mænd og Kvinder ere iklke tilladte i Nordslesvig, ikke engang dansk kunstnerisk Musil taales. Den berømte Violinistinde Frøken Frida Schytte fra København fik nemilig ikke Lov til at give Koncerter i Nordslesvig, hvorom hun havde ansøgt.

Naar de preussiske Myndigheder tro, at Nordslesvigerne paa den Maade liunne hindres i at søge Nydelsen af dansk Kunst, saa tage de fejl. Jo mere man udestænger dansk Kunst fra Nordslesvig paa den Maade, desmere søge Nordslesvigerne over Grænsen, for under en friere Luftning at forskaffe sig den højere Nydelse, Magthaverne her hjemme ikke vil tillade dem.

Sangen er altid bleven dyrket meget i Nordslesvig, og intetsteds kænder man de danske Nationalsange saa godt som her. Smaabørn, Ynglingre og Jomfruer, Mænd og Kvinder indtil Oldingealderen kan de danske Nationalsange udenad fra forste til sidste Vers. Sangen har tidt været Nordslesvigernes Tilflugt i den nationale Kamps mørkeste Dage, og naar den danske Nordslesviger hverken paa Thinge eller $i$ det offentlige Liv turde udtale sine Folelser paa det ham saa kære Modersmaal, saa gav han Sorgen eller Glæden Luft i en til Stemningen passende dansk Sang, særlig i Selskaber og Forsamlinger. Allerede strax da Preusserne i 1864 besatte Landet, udkom der et Forbud imod Afsyngelsen af danske Sange af "ophidsende“ Indhold. Dette Forbud omfattede længe kun saadanne Sange, der kunne kaldes Krigs- og Kampsange, direkte rettede imod Tyskerne, men efterhaanden fandt Politiforvaltningerne og efter dem Domstolene paa, at henføre alle mulige danske Nationalsange til de „ophidsende" altsaa forbudte Sange, og i 1894 til 96 ere mange Nordslesvigere blevne idømte undertiden betydelige Pengebøuler, for at have sunget en 
dansk Sang. Særlig fintfølende ere Amtsforstanderne og Politiet, der overvaage Foredrags- og offentlige Møder, og det er ikke sjældent, at der efter et saadant Møde er bleven mulkteret en halv Snes Mennesker, der vare tilstede ved Mødet og deltoge i Afsyngelsen af en dansk Sang, som i over 30 Aar under preussisk Herredømme er bleven sunget de tusinde Gange, uden at maaske den samme Amts, forstander eller samme Gensdarm har haft det mindste at indvende imod dens Afsyngelse. De preussiske Politikasser have i Aarene 1894, 95 og 96 slugt ikke ubetydelige Summer, der indkom som Pengebøder for Afsyngelsen af danske Sange; men alligevel kendes de danske Sange ligesaa godt nu som tidligere i Nordslesvig.

Ejendommeligt er det, at Domstolene i Almindelighed straffe de unge Nordslesvigere, der have tjent i den preussiske Armee, haardere end andre, naar de have været med til at synge danske Sange, der betegnes som ${ }_{n}$ ophidsende“. Mange Tyskere forklare dette Særsyn dermed, at man af Nænd, der have baaret Pikkelhuen og aflagt Soldatereden, venter eller endog fordrer, at de skulle opgive deres danske Sindelag Men de unge Nordslesvigere mener, at de, naar de har gjort deres Pligt som Soldater og atter ere komne hjem igjen, have Lov til at betragte sig som frie Borgere, der kunne fordre at blive behandlede som saadanne. $\mathrm{Og}$ denne naturlige 0 p fattelse af deres Stilling som frie Statsborgere opgive de ikke for nogle Pengebøders Skyld, ja ikke for haardere Straffe. De længes kun desmere efter Lejlighed til at kunne benytte sig af deres Ret til at bevise, at de trofast følge i Fædrenes Spor i Kampen for Bevarelsen af Modersmaal og Nationalitet. Thi de vide, at man venter af dem: 
For de gamle, som faldt, er der ny overalt.

De vil møde, hver Gang der bliver kaldt.

Tyskerne have i de sidste Aar arbejdet med Højtryk paa Nordslesvigs Fortyskning. Særlig have de gennem to Foreninger søgt at brede Tyskeriet, nemlig igennem „den tyske Forening for Nordslesvig “ og igennem Foreningen til Indkaldelse af tyske Nybyggere. I Spidsen for den første staar en indvandret Lærer, en født Brandenburger, og i Spidsen for den anden Forening staar en preussisk Amtsdommer. Det er betegnende for Tyskeriet i Nordslesvig, at Embedsmandene altid staa i Spidsen for det, og at disse Embedsmand som oftest ere indvandrede Preussere, der mene, at de i en Haanderending kan gøre det af med Danskheden i Nordslesvig. Deres Stormløb i Treaaret 1894 til 96 imod dansk Sprog, dansk Nationalitet og dansk Kultur i Nordslesvig blev derfor ogsaa Hastværksarbejde oy usselt ledet. Hertil kom, at den Mand, der stod i Spidsen for Regeringen i Slesvig, ligeoverfor Forholdene i Nordslesvig var slaaet med Blindhed. Baale han og de Organer, vore Magthavere raade over, lode sig lede af uduelige Hornblasere, der $\mathrm{i}$ deres drengeagtige Glæde over at være blevne antagne som Spillemænd, holdt sig selv for store Strategikere og blæste Signaler efter eget Tykke. Derfor mislykkedes Stormløbet ogsaa over hele Linien, saa besindige og klartseende Tyskere have begyndt at advare imod at blive ved med denne Kampmaade.

„Frem i Tugt og Takt! Frem til Værk og Vagt!“ lød det imidlertid fra Række til Række i den nordslesvigske Folkehær. Støt og rolig stillede dens tre Hovedafdelinger: Vælgerforeningen, Sprogforeningen og Skoleforeningen sirg 
til Forsvarskamp paa Skandsen, mens Losenet gik fra Mand til Mand: „Hold din Tanke hed!

Virk og vær bered!"

Den nordslesvigske Vælgerforening havde imidlertid gode Dage, thi i Aarene 1894 til 96 faldt der ingen større Valg, saasom almindelige Rigsdags- og Landılagsvalg. Ku n et Suppleringsvalg til Landdagen for 2den Kreds fandt Sted, og ved dette holdt de danske Valgmænd fuldt ud Pladsen. Istedetfor den ved Dølen afgaaede Landdagsmand Hans Lassen valgtes Udgiveren af det danske Dagblad „Hejmdal“ og Medudgiver af "Sønderjydske Aarbøger", H. P. Hanssen-Nørremölle i Aabenraa til Repræesentant for 2den slesvigske Valgkreds til den preussiske Landdag. Som født i Sundeved af en anset dansk Familie, og som Vælgerforeningens mangeaarige anerkændt dygtige Sekretær, havde Befolkningen i Sundeverd og paa Als, ja i hele 2den Valgkreds til den preussiske Landdag længe udşet ham for en Førerpost. Nu gaves der Lejlighed til at vise ham den fortjente Tillid, og fuldtallig mødte alle danske Valgmænd i Kredsen og kaarede ham enstemmig til Landdagsmand. - Vælgerforeningen lod dog afholde en hel Del politiske Møiler i de forskellige Egne af Nordslesvig, og disse Møder vare alle meget godt besøgte, flere endda overmaade godt, og Stemningen var paa dem alle frejdig og loftende.

Sprogforeningen eller rettere „Foreningen til det danske Sprngs Bevarelse i Nordslesvig" arbejdede ogsaa i de sidstforløbne 3 Aar med stor Velsignelse. Den arbejder som bekandt for sin Opgave navnlig ved Udbredelsen af god dansk Lresning. Bogsamlinger holdes, eventuelt oprettes i ethrert Sogn i Nordslesvig, hvor der findes en patriotisk 
Mand, der uden Vederlar paatager sig at give Samlingen Husly ng at udlaane Bogerne. I enkelte større Sogne findes endog to Bogsamlinger, og i Gennemsnit benyttes disse Bogsamlinger særdeles flittig baale af Unge og Gamle. Bornebygrer og Billedvarker, historiske og geografiske Lareog Læsebøger og Kort udleltes som Foræringer og Præmier i tusindvis, et Børneblad og en Almanak, særlig skrevet for Nordslesvig, udgares, den sidste i mange tusinde Exemplarer.

Og saa den tredje store Folkehærafdeling: „Den nordslesvigske Skoleforening". Den sendte arrlig hundreder af kontirmerede Drenge og Piger, hvis Forældre enten slet ikke eller kun merct daarlig selv havde Raad dertil, paa danske Fortsxttelses- og Hojskoler, for at de der kunde indhente det, der var bleven forsømt i de preussiske Statsskoler. Denne Forenings Virksomherl er af umaadelis Betydning for den opvoxende Ungdom, de kommende Slægter og for den nordslesvigske Befolknings Fremtid i det Hele taget. Det nytter ikke, at Preusserne sige: vi have Skolen og med den Fremtiden. Den preussiske Folkeskole er altfor meget en "Underofficersskole", Korporalstokken markes for tydelig i den, og den arbejuler med ,paabudte Overbevisninger". Men disse paabudte Overbevisninger holle ikke i Fremtiden, de bære ingen Spirekraft i sig og fæstne sig ilke i Barnesjælen. Det rette Lirssalt for Ungdommens Opdragelse mangler. En laa uomtvistelige historiske Sandheder, paa Aandsfrihed og Selvbestemmelse or paa Kristendommens ikke med Statsinteresser blandede ophojede Grundsætninger lıvilende Undervisning, er ikke det fremtrædende Kendemærke for den preussiske Statsskole. Hval Under da, at de 
nordslesvigske Elever fra de danske Fortsættelses- og Højskoler vender hjem med et ganske andet og frejdigt Syn paa Livet, baade Folke- og Aandslivet! $O g$ at ikke blot velhavende Forældres Børn skulle nyde dette Gode, men at ogsaa mangfoldige Børn af mindre velstillede og fattige Forældre kunne faa Del deri, det arbejder den nordslesvigske Skoleforening for.

Derfor synger den danske Nordslesviger ogsaa med den danske Sanger:

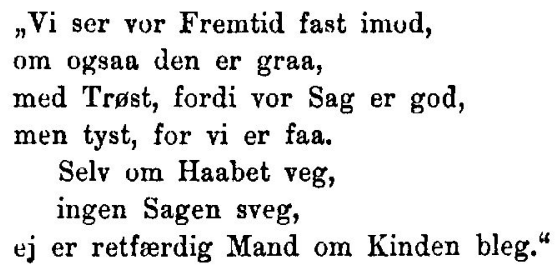

